DOI https://doi.org/10.15589/znp2019.4(478).3

УДК 65.012.2:66

\title{
THE GENESIS AND THE MODERN PARADIGM OF STRATEGIC ENTERPRISE MANAGEMENT
}

\section{ГЕНЕЗИС ТА СУЧАСНА ПАРАДИГМА СТРАТЕГІЧНОГО УПРАВЛІННЯ ПІДПРИЕМСТВОМ}

\author{
Olga B. Kalaman \\ kalaman.olga@gmail.com \\ ORCID: 0000-0001-5586-7654
}

\author{
О. Б. Каламан, \\ канд. екон. наук, доцент, докторант
}

\section{Odessa National Academy of Food Technologies, Odessa}

Одеська національна академія харчових технологій, м. Одеса

\begin{abstract}
The article is devoted to the study of the genesis of theories of strategic management, from the theory of strategic planning, to the theory of strategic management. Different interpretations and definition of the essence of management are analyzed in the work with the purpose of revealing approaches to the disclosure of the content of management. The research carried out by the author showed that, at this moment of time, the peculiarities of the process of strategic management at the enterprises have not been sufficiently investigated; therefore, in this paper a theoretical and methodological position is presented in the part of organizational, methodological and informational support of the process of formation of the enterprise strategy. The purpose of the research is to provide scientific substantiation and development of the theory of strategic management in the part of organizational and methodological support of the strategy formation process, which allow to provide qualitative analytical substantiation of strategic management decisions of enterprises in the long-term perspective. To solve the research problems, the principles of dialectical logic, the unity of logical and theoretical, system analysis, the problem-target approach, classification methods, and expert assessments were used. The work is proved strategic management is given a leading role in the direction of further development of industrial production and increase of its efficiency.
\end{abstract}

Key words: strategy; strategic management; enterprise management; theory of strategic management; strategic planning, enterprise competitiveness; enterprise.

Анотація. Стаття присвячена дослідженню генезису теорій стратегічного управління, починаючи від теорії стратегічного планування до теорії стратегічного управління. В роботі докладно проаналізовані різні трактування і визначення сутності управління з метою виявлення підходів до розкриття змісту управління. Проведені автором дослідження показали, що на цей момент часу особливості процесу стратегічного управління на підприємствах досліджені недостатньо, тому в цій роботі представлене теоретичне та методичне положення в частині організаційно-методичного та інформаційного забезпечення процесу формування стратегії підприємства. Метою проведеного дослідження $є$ наукове обгрунтування і розвиток теорії стратегічного управління в частині організаційно-методичного забезпечення процесу формування стратегії, що дозволяють забезпечити якісне аналітичне обгрунтування стратегічних управлінських рішень підприємств в довгостроковій перспективі. Для досягнення поставленої мети дослідження використовувалися принципи діалектичної логіки, єдності логічного і теоретичного, системного аналізу, проблемно-цільовий підхід, методи класифікації, експертних оцінок. У роботі доведено, що стратегічному управлінню відводиться провідна роль в напрямі подальшого розвитку промислового виробництва і підвищенні його ефективності. Зазначено, що підприємство - це самостійний, організаційно-відокремлений господарюючий суб'єкт з правами юридичної особи, який виробляє і реалізує продукцію, виконує роботи, надає послуги. Як висновок автор зосереджує увагу на тому, що підприємство є одним з основних інститутів сучасної економічної системи і являє собою відокремлений суб'єкт економічної діяльності, який здійснює свої функції у зовнішньому економічному середовищі, до якого належать споживачі, постачальники, держава, конкуренти, природні умови і суспільство загалом. Особливо наголошується на тому, що промислове підприємство фактично служить інструментом розподілу ресурсів в економіці між альтернативними можливостями їх використання.

Ключові слова: стратегія; стратегічне управління; управління підприємством; теорії стратегічного управління; стратегічне планування; конкурентоспроможність підприємства; підприємство. 


\section{FORMULATION OF THE PROBLEM}

The formation of a market economy in Ukraine with the associated formation of its institutes, instruments and economic mechanisms creates the preconditions for the formulation of the fundamental provisions of organizational and methodological support for the process of strategy development. The number of top managers who are clearly aware of the acute need for strategy, implementation of strategic management and the active use of methodological tools for strategic analysis in the process of substantiating strategic development priorities is constantly increasing. Formation and use of effective organizational and methodological support of the process of strategic management on a permanent basis becomes an indispensable condition for the prosperity of each enterprise.

At the same time, in the foreign and Ukrainian economic literature, the integrated system of organizational and methodological support for strategic management, which defines the peculiarities of the content of the investigated aspects of strategic management is not yet sufficiently developed. This categorical apparatus was not finally formed in this scientific field; improvement of the existing theoretical and methodological aspects is necessary, as well as the development of completely new instruments and modern methods of conducting strategic analysis in the process of strategic management. Such circumstances determine the necessity of expanding research devoted to the development of strategic management of enterprises.

\section{ANALYSIS OF RECENT RESEARCH AND PUBLICATIONS}

Fundamental aspects and specific questions of strategic management have been reflected in the writings of such foreign authors as: R. Ackoff [1], I. Ansoff [2], R. Bishop [3], R. Braley [4], R. Grant [5], M. Meskon [6], M. Albert, F. Hedouri, A. Thompson [7], A. Strickland, T. Copeland [8], T. Koller, J. Murrin, S. Myers [9], M. Porter [10], F. Ch. Evans [11], R. S. Kaplan [12], D. P. Norton, D. Aaker [13].

\section{SEPARATION OF PREVIOUSLY UNRESOLVED PARTS OF A COMMON PROBLEM}

The proposed scientific vision of organizational and methodological support for the process of strategic management is based on the synthesis of methodological approaches and theoretical solutions proposed by these researchers. However, in appreciation of the scientific contribution of the listed scientists, it should be emphasized that at this moment of time, the peculiarities of the process of strategic management at enterprises are not sufficiently explored. The complexity, ambiguity and versatility of this problem, its insufficient scholarship in modern domestic and foreign science, the need for adequate theoretical conditions of the theoretical provision and organizational and methodological provision of the strategic management process, as well as the high practical significance contributed to the choice of the topic of the article.

\section{THE AIM OF THE RESEARCH}

The purpose of the research is to provide scientific substantiation and development of the theory of strategic management in the part of organizational and methodological support of the strategy formation process, which allow to provide qualitative analytical substantiation of strategic management decisions of enterprises in the long-term perspective.

\section{METHODS, OBJECT AND SUBJECT OF STUDY}

The principles of dialectical logic, unity of logical and theoretical, system analysis, problem-target approach, methods of classification, expert assessments were used to solve the problems of the research. The object of the research is the process of strategic management of the enterprise. The subject of the research is theoretical, methodological and applied aspects of development of mechanisms of strategic development of modern enterprise.

\section{BASIC MATERIAL}

At present, the development of industrial enterprises is largely driven by the effectiveness of strategic management, capable of providing high end results of production and economic activity, and allows companies in the short and long term to successfully develop in a competitive environment, that is, in a medium subject to rapid, radical and often unpredictable changes .

At first, the term "strategy" was used only in the terminology of military art ("military strategy") and marked the science of warfare, covering the theory and practice of preparing for war, its planning and conduct. By its very nature, the military strategy was a way of achieving victory in the war by defining the purpose, general plan and systematic application of measures to counteract the enemy in the light of changing circumstances and situation. Strategy, as a concept, was among the most administrative terms in the middle of the XX century, when the problem of reaction to unexpected changes in the external environment became very important.

At present, the issue of determining the organization's strategy is considered to a significant amount of publications of both domestic and foreign authors. Like most terms in management, strategy is a widespread concept that has different interpretations for different people. At the same time, some authors consider mainly some aspects of the development and implementation of a strategy that is applied in nature. According to other researchers, the concept of strategy is analyzed in terms of methodology - it is comprehensive and in-depth. Thus, we note that the definition of a strategy cannot be universal and unique in view of the complexity of the concept. 
But the definition of most authors, both modern and past century, in our opinion, are rather similar and have much in common.

According to G. Mintzberg, B. Alstrand and J. Lampel's strategy is a set of five " $p$ ": plan (direction of development), principle of behavior (observance of a certain model of behavior), position (the location of certain goods in specific markets), prospect (the main way of doing business), ploy (a special maneuver in order to outwit, deceive or confuse competitors) [14].

Authors such as A. Thompson and A. Strickland define a strategy as an organization management plan aimed at strengthening its position, satisfying consumers, and achieving its goals [7].

A similar definition of the strategy can be found in M. Meskon, M. Albert and F. Hedouri, who argue that the strategy is essentially a detailed, comprehensive and integrated plan designed to ensure the existence of the mission of the organization and the achievement of its goals [6].

A.V. Tebekin considers the strategy of the company as a system of large long-term tasks, the solution of which is aimed at achieving the objectives of the organization [15].

R. Grant gives the definition of strategy in a more concise form. He argues that the strategy is to plan the ways in which an organization or individual can achieve its goals [5].

G.B. Kleiner defines such a concept as a "comprehensive strategy", which, in his opinion, covers all the spheres and subsystems of the enterprise, having a multilayered structure of the sandwich pyramid. It is the enterprise as the "processor of strategies" that transforms the external input and own strategies into an initial strategy that is used as a guide to action and in the defined by the administration limits and forms is informed to the business community. Such a strategy is called enterprise policy [16].

In the definition of L. V. Glukhikh there is the idea of interconnection through the process of development and implementation of the strategy between the existing and prospective resources of the enterprise, the longterm goals of its development and its own strategy as a sequence of stages, which interconnects resources and goals, and results in specifying the way of enterprise development [17].

At the same time, the economic strategy is the basis for providing the necessary parameters for the economic efficiency of the industrial enterprise within the framework of the strategic management system. In fact, the strategy produces rules and techniques for the cost-effective achievement of strategic goals for the development of an industrial enterprise. Considering the evolution of approaches to management of an industrial enterprise, it should be noted that these approaches are oriented more to the growing level of instability of the environment than to solving the question of the predictability of the future.
The generally accepted classification of approaches to enterprise management includes four systems [18]:

- management is based on performance monitoring, or budgeting (since 1900);

- extrapolation management, or long-term planning, when the pace of change in the enterprise environment accelerates, but the future can still be predicted on the basis of past trends (since 1950);

- management based on prediction of changes, or strategic planning, where the pace of environmental change is further accelerated, however, to predict the risks and threats of the external environment is possible with further inclusion in the strategic plan of the enterprise development (since 1970);

- management based on flexible emergency solutions, or strategic management, when many important tasks arise so rapidly that they cannot be foreseen in a timely manner (since 1990).

As the term, strategic management arose in the 60's and 70's of the XX century as a result of further development of management systems associated with changes in problems and conditions of production, and since the 90' $\mathrm{s}$ it gradually begins to be applied in the practical activities of enterprises. Using only long-term planning, which involves the continuation of historically established trends in the enterprise for the future period and is based on the principles of extrapolation, could no longer meet all the changes that have begun to occur in a market economy. The transition from long-term planning to strategic planning, and then to strategic management, has become vital for many enterprises operating in a market economy, due to the saturation of demand, the fundamental changes taking place in the technologies, industries and sectors of production, as well as in international markets and globalization.

Globalization acts as an external factor that transforms the structure of the industrial sector of the economy, and has recently increasingly strengthened its influence on all sectors of the economy. Being a process in its content, which increases the interconnection between technological and financial flows, the exchange of goods and services, globalization unites markets of production from different countries [19]. All these changes taking place both in the global economic system as a whole and in the economy of individual countries have led to the need to shift the attention of the management of enterprises to their surroundings, to the external environment, in order to timely and adequately respond to changes that occur in it.

In the process of development of the theory of strategic management certain directions have been formed that have their own peculiarities $[2,10,14,20]$ :

1) cognitive (G. Simon, J. March): the development of a strategy is more considered in terms of psychology, as a mental, that is, cogitative intellectual, process of knowledge of the strategist; 
2) design (F. Selznik, W. Newman, C. Andrews): the formation of a strategy is the formation of a perspective, a concept, a well-considered process in which particular attention is paid to the assessment of the external and internal situation. At the same time, responsibility for the formation and quality of the strategy lies with the executive who makes decisions;

3) planning (I. Ansoff): the strategy is a logical result of a conscious controlled process of formal planning, based on a competent and comprehensive study of the environment and conducting a strategic analysis. It is necessary to foresee the future and prepare for it. Planners should deal with developing of strategies. At the same time, the responsibility for implementing the strategy lies with the manager;

4) entrepreneurship (J. Schumpeter, A. Cole): the strategy exists in the mind of the manager in the form of a perspective. The choice of strategy is based on his intuition, prediction, and the success of the choice depends on the entrepreneurial talent and experience that actually reduces the formation and promotion of the strategy to the model of one person's behavior;

5) learning (C. Lindblom, K. Wake, J. Quinn): the formation of a strategy is a developing process, which is associated with the accumulation of knowledge and learning. The staff of the organization is thus considered as a set of active elements, internal entrepreneurs or potential strategists that propose changes to the team of senior managers;

6) culture (E. Renman, R. Normann): the process of forming a strategy is presented as a result of the efforts of a huge number of employees of the company, that is, as a collective process of social interaction, based on common beliefs and understanding for all members of the organization;

7) configurations (A. Chandler, G. Mintzberg, D. Miller): the development of the organization in time (life cycle) represents a certain cyclic process of alternating states of rest and change, the transformation of organization from one stable state to another;

8) positioning (D. Schendel, K. Hatten, M. Porter): great attention is paid to the analytical process of selecting and updating strategies. For each industry there is a limited number of effective strategies. The main role in the development of strategy is played by the analysts, representing the results of their calculations to management, controlling the choice of strategy;

9) the authorities (G. Allison, J. Pfeffer, G. Salansik): the formation of a strategy is a process of fighting individuals and their coalitions for their personal and group interests, that is, in essence, the process of negotiation and the achievement of compromises;

10) the external environment (M. Hannan, J. Freeman): the main driving force in creating a new strategy organization is the external environment, the hostility of which must be overcome. Representatives of this school considered not only economic resources as resources of the organization, but also symbolic ones (image, reputation, etc.).

At the current stage of development of the Ukrainian economy at domestic industrial enterprises, along with the so-called business model of common sense (the content of which consists in trying to buy cheaper and sell more expensive), more and more applications are found by models presented by Western firms and joint ventures on the territory of Ukraine. This is, first of all, about external changes and technological innovations in the field of management. In addition, at some domestic enterprises to date, models based on the previous experience of Soviet management are used.

Applied models in modern conditions are not able to cope with the numerous challenges of the environment, at the same time models used by Western business structures cannot be automatically transferred to the Ukrainian conditions of management of industrial production, and the past, "Soviet" style of management of production systems, strong with its traditions and conservative, is often simply not compatible with the fast-moving external environment, its uncertainty and its alternative. In connection with this, the main direction of production and economic activity of the enterprise is solving the problem of ensuring its sustainability in the long run, increasing the competitiveness of production on the basis of denationalization, the formation of investment attractiveness, improvement of production processes and the efficient use of material and technical resources, i. e., measures that ensure continuous process of steady development, and organization of works on creation and realization of competitive advantages of the enterprise [21].

There are a number of definitions that emphasize certain aspects and specifics of strategic management: the parameters of the organizational environment, the definition of long-term goals and ways to achieve them, or the activities of the organization. Here are some of these definitions.

B. G. Litvak defines strategic management as a process that allows the organization to be developed in accordance with the adopted strategy, its flexibility and mobility, necessary for timely adjustments of strategic decisions when changing external or internal conditions of the organization's operation or the course of implementation of strategic decisions adopted earlier [22].

According to O. S. Vikhansky, strategic management is a management of the organization based on a human potential as the basis of the organization, orienting the production activity to the needs of consumers, flexibly responding and timely making changes in organizations that meet the challenge from the environment and allow you to seek competitive advantages that together enable the organization to survive in the long run, while achieving its goals at the same time [23].

G. von Krug and M. Keene note that strategic management activities are aimed at providing a strategic 
position that should ensure the long-term viability of the organization in changing circumstances [24].

A number of researchers believe that in general, strategic management is the activity of senior management, consisting of the allocation of perspective desired areas of enterprise development and, indicate that it is associated with the formulation of goals and objectives, as well as the maintenance of effective interaction between the enterprise and its external environment that allows you to achieve the goals that correspond to the internal capabilities of the enterprise and allow you to remain receptive to the external requirements and challenges of the environment [2].

On the other hand, strategic management can be considered as a process of adoption and implementation of strategic decisions, the central element of which is a strategic choice, based on a comparison of its own resource potential of the enterprise with the opportunities and threats of the external environment in which it operates. At the same time, the strategy can be considered as the main link between what the company wants to achieve its goals and the line of behavior chosen to achieve these goals [25].

The prerequisites for the emergence of strategic management were:

- $\quad$ an idea of the desired results of the company in the future;

- $\quad$ possession of the ability to timely identify the problems of the enterprise and the availability of mechanisms for their solution;

- management reaction in the event of threats to enterprise stability;

- minimizing losses and taking measures to prevent their happening;

- $\quad$ orientation of the enterprise's potential for strategic tasks based on the development of goals, their timely adjustment, the provision of necessary positions in the market, etc.

The essence of strategic management is the interconnection of strategic management decisions, concrete steps to ensure a rapid response of the management of the enterprise to change the external environment and, as a consequence, adjusting the general goals and directions of enterprise development, both for the near and longterm prospects (Fig. 1).

Strategic management of an enterprise, acting as one of the subjects of market relations, is based on the following basic provisions [26]:

1. Enterprise - a complex socio-economic system, which has a number of features and peculiarities:

- the establishment of the system takes place in order to carry out the mission and achieve its goals;

- creation of material goods (services) using available resources;

- the cost of production of goods (services) should be comparable to the results of activities;

- against the background of the general multifaceted and multicriterial tasks of managing, the formalization of the latter in many cases is difficult;

- the processes taking place in the control system are very dynamic;

- the internal environment of the system - is the internal components of the organization, defining its activities, and characterized by complex interconnections between them;

- the enterprise must necessarily develop, changing, if necessary, the guidelines of its development;

- mandatory presence of the apparatus in the enterprise structure, which performs the role of management, has its own functional purpose, structure, as well as the approved system of rules of conduct.

2. The external environment of an enterprise can influence the effectiveness of its activities and implementation of the strategy. In fact, the company is not able to significantly affect the external environment. But since it is a subject of an open type, therefore, the effectiveness of its activities will depend on how quickly it can adapt to the prevailing conditions.

3. There is no definite, standard, unified set of rules, the order of solving strategic tasks does not exist. All strategies, as well as the results of the impact of various strategic management tools, are unique.

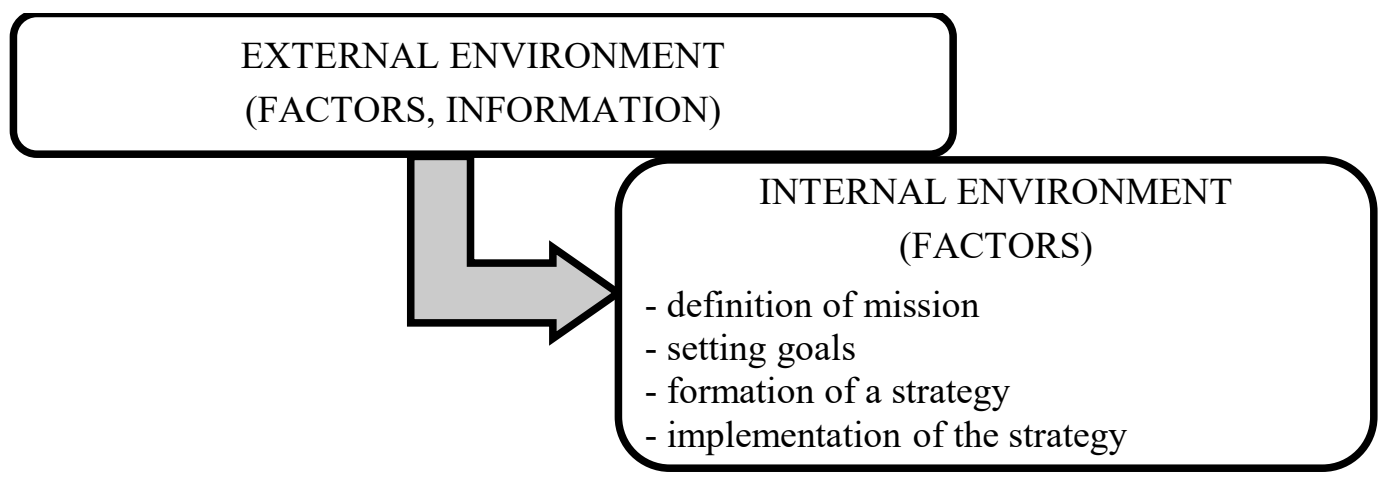

Fig. 1. Interconnection of the main elements of the strategic management process 
4. The main components of any enterprise, as a subject of market relations, are:

- goods or services for which it is created;

- missions, goals, development strategies;

- a technological component that determines the process of transforming existing resources into labor products;

- internal and external environment.

It is important to note that strategic management is situational in nature (it envisages creative and varied decisions depending on the real or predicted situation), the systemic nature (depending on the system itself - the object of strategic management, its level, scale, areas of activity, etc.) and competitive character (aimed at achieving competitive advantages).

Along with the potential and competitiveness, we consider the strategy of the company as the main, determining component of the strategic management (Fig. 2).

The potential of the enterprise is a summary value that characterizes all possibilities of the enterprise with output and service provision. It is determined by all, available at the disposal of the enterprise factors of production, for example, natural and human resources, capital, entrepreneurship. Each factor takes its place in the enterprise and has its specific function. The resources that the enterprise uses can also be classified as follows:

1. Material resources are means of organization, enterprises that are physical and financial assets: production equipment; availability of inventory; cash; financial condition of the enterprise, etc.

2. Technological resources (methods of manufacturing products).

3. Information resources (data on the internal and external environment). Here we note that the special significance of information is stipulated by its properties, since for modern industrial enterprises the level of correspondence of information to its real state in the process of making a managerial decision determines the level of achievement of the given result in the planned time [27].

4. Organizational resources (decision-making system, system of planning, control, motivation, etc.).

\section{DISCUSSION OF THE RESULTS}

In the formation of strategic management, its main direction is to increase the efficiency of production and eco- nomic activity of the enterprise due to more efficient use of available material and intangible resources, namely:

- reduction of material stocks;

- reduction of stocks of work in progress;

- inventory of tangible assets;

- improvement of equipment usage indicators;

- achievement of saving of material resources, etc.

With regard to Ukraine, concerning the situation in the world economy, the question of achieving the competitive advantages of Ukrainian enterprises and increasing the competitiveness of Ukrainian products in the world market is, in our opinion, very significant conditions for economic growth. In its turn, it is possible to increase the competitiveness of domestic products through modernization of production, maximum attraction of foreign investors, the use of their experience and technologies, as well as the development of their own innovation activities [28]. The factors that affect the competitiveness of an enterprise should be developed by the unified principles of strategic management [29], which may include:

- weighted and justifiable process of determination of goals and strategies of the enterprise. It is also an effective solution in the field of new products, new technologies, and access to new markets, the issue of promoting products in the already mastered markets, occupation of certain market segments, and so on;

- conducting a continuous search for new forms and activities in order to increase the competitiveness of the enterprise;

- $\quad$ scheduling for shorter periods of time and for individual units should be more specific and detailed than long-term prospects, as the amount of reliable information about the future is limited, and the range and rate of change in this information tend to increase over time;

the establishment of a specific relationship between the internal elements of the enterprise system and the environment, the leading and guided of the enterprise.

\section{CONCLUSIONS}

Thus, strategic management is given a leading role in the direction of further development of industrial production and increase of its efficiency.

An enterprise is an independent, organizationally separated economic entity with the rights of a legal entity

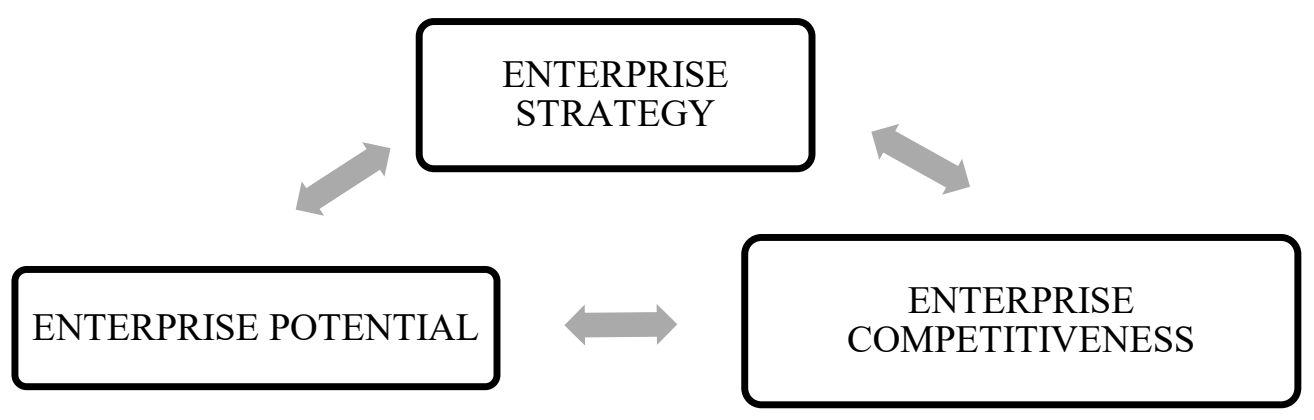

Fig. 2. The main components of strategic management 
that produces and sells products, performs work, provides services.

The enterprise is one of the main institutes of the modern economic system and is a separate entity of economic activity, which carries out its functions in the external economic environment, which includes consumers, suppliers, the state, competitors, natural conditions and society as a whole. An industrial enterprise actually serves as a tool for distributing resources in the economy between alternative opportunities for their use. The difference of the industrial enterprise from other economic entities is that it:

- is a large organizational and financially designed unit;

- is a separate legally independent economic agent;

- performs a special function in the economy: receives resources for the production of goods and services;

- independently chooses the type of internal organization;
- ensures existence and development due to the difference between total revenue and expenses. In this case, profits in the company's activity serves as one of the main goals, as one of the significant criteria for its behavior.

Since industrial production is defined as a set of economic activities for mining, industrial production and processing of raw materials, including the provision of appropriate services, in the context of the emergence of a market economy in Ukraine, this sphere of activity has undergone the most significant negative changes that will be investigated in further scientific works. The collapse and violation of many economic ties, material and technical support, as the results of the shock reforms in the economy in the early 1990's, the subsequent crisis in 1998 and the global financial crisis of 2008-2009, could not but affect the quality and production volumes of industrial production and financial position of the majority of domestic enterprises of different industries.

\section{REFERENCES}

[1] Ackoff, R. L. (2002). Planirovanie budushhego korporaczii [Planning for the future of the corporation]. Moscow : Sirin [in Russian].

[2] Ansoff, I. (2010). Strategicheskoe upravlenie [Strategic Management]. Moscow : Bizneskom [in Russian].

[3] Dorf, R., Bishop, R. (2004). Sovremenny`e sistemy` upravleniya [Modern control systems]. Moscow : Laboratory of basic knowledge [in Russian].

[4] Braley, R. (2010). Princzipy' korporativny'kh finansov [Principles of Corporate Finance]. Moscow : Olymp-Business. [in Russian]

[5] Grant, R. (2012). Sovremennyiy strategicheskiy analiz [Modern Strategic Analysis]. St. Petersburg : Peter. [in Russian]

[6] Meskon, M., Albert, M., Hedouri, F. (1997). Osnovyi upravleniya [Fundamentals of Management]. Moscow : Case. [in Russian]

[7] Thompson, A., Strickland, A. (1998). Strategicheskiy menedzhment: iskusstvo razrabotki i realizatsii strategii [Strategic Management: The Art of Developing and Implementing a Strategy]. Moscow : Banks and exchanges. [in Russian]

[8] Copeland, T., Koller, T., Murrin, J. (2005). Stoimost' kompanij: oczenka i upravlenie [The Cost of Companies: Evaluation and Management]. Moscow : Publishing Company CJSC "Olymp-Business". [in Russian]

[9] Braley, R., Myers, S. (2008). Princzipy’korporativny`kh finansov [Principles of Corporate Finance]. Moscow : Olimp-Business. Ch. 18. [in Russian]

[10] Porter, M. (2010). Konkurentsiya [Competition]. Moscow : Williams. [in Russian]

[11] Evans, F. Ch., Bichon, D. M. (2004). Oczenka kompanij v sliyaniyakh i pogloshheniyakh: sozdanie stoimosti v chastny'kh kompaniyakh [Evaluating companies in mergers and acquisitions: creating value in private companies]. Moscow : Alpina Publisher. [in Russian]

[12] Kaplan, R. S., Norton, D. P. (2001). The Strategy Focused Organization: how balanced scorecard companies thrive in the new business environment. Harvard Business School Publishing Corporation. USA.

[13] Aaker, D. (2007). Biznes-strategiya ot izucheniya ry`nochnoj sredy` do prinyatiya besproigry`shny`kh reshenij [A Business Strategy from Studying the Market Environment to Making Win-Win Solutions]. Moscow : Exmo. [in Russian]

[14] Mintzberg, G., Alstrand, B., Lampel, J. (2013). Strategicheskie safari: tur po debryam strategicheskogo menedzhmenta [Strategic safaris: a tour of the wilds of strategic management]. Moscow : Alpina Publisher. [in Russian]

[15] Tebekin, A. V. (2012). Strategicheskiy menedzhment: Uchebnik dlya bakalavrov [Strategic Management: Textbook for Bachelors]. Moscow : Yurait. [in Russian]

[16] Kleiner, G. B. (2008). Strategiya predpriyatiya [Strategy of the enterprise]. Moscow : CASE. [in Russian]

[17] Glukhikh, L. V. (2012). Neobhodimost i tselesoobraznost primeneniya strategicheskogo podhoda k organizatsii promyishlennyih predpriyatiy $\mathrm{v}$ usloviyah konkurentsii [Necessity and expediency of applying a strategic approach to the organization of industrial enterprises in a competitive environment]. Economic sciences. no. 4 (89), pp. 49-53.

[18] Polischuk, S. V. (2013). Suschestvennyiy aspekt i analiz podhodov k byudzhetnoy organizatsii. Innovatsionnaya ekonomika [An Essential Aspect and Analysis of Approaches to Budgeting Organization]. Innovative Economics. no. 8 (46), pp. 331-338.

[19] Bezrukova, N. V., Svichkar, V. A. (2016). E'konomicheskaya globalizacziya: analiz osnovny'kh protivorechij i posledstvij [Economic globalization: analysis of the main contradictions and consequences]. Economics and national economy management, no. 3 (56), pp. 62-67.

[20] Simon G., Smithburg, D., Thompson, B. (1995). Menedzhment v organizatsiyah [Management in Organizations]. Moscow : Economics. [in Russian]

[21] Granberg, A. G. (2001). Strategiya territorialnogo sotsialno-ekonomicheskogo razvitiya: ot idei k realizatsii [Strategy of Territorial Socio-Economic Development: From Idea to Realization]. Questions of Economics. no. 9, pp. 15-27. 
[22] Litvak, B. G. (2013). Strategicheskoe upravlenie [Strategic management]. Moscow : Yurayt. [in Russian]

[23] Vikhansky, O. S. (2000). Strategicheskoe upravlenie [Strategic management]. Moscow : Gardariki. [in Russian]

[24] Von Krog, G., Keene, M. (1999). Peredacha znaniy na predpriyatii: osnovnyie etapyi i faktoryi vliyaniya [Transfer of knowledge in the enterprise: the main phases and influencing factors]. Problems of theory and practice of management. no.4, pp. 4-7.

[25] Kalaman, O., Volodina, O., Mandrikin, D. (2018). Innovatsionnaya strategiya razvitiya, formirovanie sovremennogo predpriyatiya. Ekonomika pischevoy promyishlennosti [Innovative development strategy formation of the modern enterprise]. Food Industry Economics. no. 2 (10), pp. 75-82.

[26] Carloff, B. (1991). Biznes-strategiya: konczepcziya, soderzhanie, simvoly[Business Strategy: Concept, Content, Symbols]. Moscow : Economics [in Russian]

[27] Babikova, A.V., Shevchenko, I.K. (2012). Integrirovanny`e informaczionny`e sistemy’: analiz i perspektivy’ vnedreniya v proczess upravleniya predpriyatiem [Integrated information systems: analysis and prospects for implementation in the enterprise management process]. Problems of Economics. no. 2, pp. 23-26.

[28] Volsky, A. I. (2001). Razvitie promyishlennosti yavlyaetsya osnovoy dlya pod'ema ekonomiki stranyi [The development of industry is the basis for the rise of the country's economy]. The Economist. pp. 11-15.

[29] Vereskun, M. V. (2012). Formirovanie sistemyi upravleniya konkurentosposobnostyu krupnyih integrirovannyih promyishlennyih predpriyatiy [Formation of a competitiveness management system for large integrated industrial enterprises]. Basics of Economics, Management and Law. № 3 (3), pp. 55-58.

\section{СПИСОК ВИКОРИСТАНОЇ ЛІТЕРАТУРИ}

[1] Акофф, Р. Л. (2002). Планирование будущего корпорации. Пер. С англ. Москва : Сирин. 256 с.

[2] Ансофф, И. (2010). Стратегический менеджмент. Москва : Бізнеском.

[3] Дорф, Р., Бишоп, Р. (2004). Современные системы управления. Москва : Лаборатория базовых знаний.

[4] Брели, Р. (2010). Принципы корпоративных финансов. Москва : Олімп-Бізнес.

[5] Грант, Р. (2012). Современный стратегический анализ. Санкт-Петербург : Пітер.

[6] Мескон, М., Альберт, М., Хедурі, Ф. (1997). Основы управления. Москва : Справа.

[7] Томпсон, А., Стрікленд, А. (1998). Стратегический менеджмент: искусство разработки и реализации стратегии. Москва : Банки та биржы.

[8] Коупленд, Т., Коллер, Т., Муррин, Дж. (2005). Стоимость компаний: оценка и управление. Москва : Издательская компания ЗАТ «Олимп-Бизнес».

[9] Брейлі, Р., Майєрс, С. (2008). Принципы корпоративных финансов. Москва : Олимп-Бизнес, гол. 18.

[10] Портер, М. (2010). Конкуренция. Москва : Вильямс.

[11] Еванс, Ф. Ч., Бішон, Д. М. (2004). Оценка компаний при слиянии и поглощении: создание стоимости в частных компаниях. Москва : Издательство Альпина.

[12] Kaplan, R. S., Norton, D. P. (2001). The Strategy Focused Organization: how balanced scorecard companies thrive in the new business environment. Harvard Business School Publishing Corporation. USA.

[13] Аакер, Д. (2007). Бизнес-стратегия изучения рыночной среды для принятия беспроигрышных решений. Москва : Ексмо.

[14] Мінцберг, Г., Альстранд, Б., Лампель, Дж. (2013). Стратегические сафари: экскурсия по недрам стратегического управления. Москва : Издательство Альпина.

[15] Тебекін, А. В. (2012). Стратегический менеджмент : учебник для бакалавров. Москва : Юрайт.

[16] Клайнер, Г. Б. (2008). Стратегия предприятия. Москва : Справа CASE.

[17] Глухих, Л. В. (2012). Необходимость и целесообразность применения стратегического подхода к организации промышленных предприятий в конкурентной среде. Экономические науки. Вып. 4 (89), с. 49-53.

[18] Поліщук, С. В. (2013). Основний аспект та аналіз підходів до організації бюджету. Інноваційна економіка. Вип. 8 (46), c. 331-338.

[19] Безрукова, Н. В., Свичкарь, В. А. (2016). Экономическая глобализация: анализ основных противоречий и последствий. Экономика и управление начиональной экономикой. Вып. 3 (56), с. 62-67.

[20] Саймон, Г., Смитбург, Д., Томпсон, Б. (1995). Менеджмент в организациях. Москва : Экономика.

[21] Гранберг, А. Г. (2001). Стратегия территориального социально-экономического развития: от идеи к реализации. Вопросы экономики. Вып. 9, с. 15-27.

[22] Литвак, Б. Г. (2013). Стратегический менеджмент. Москва : Юрайт.

[23] Виханський, О. С. (2000). Стратегический менеджмент. Москва : Гардарики.

[24] Фон Крог, Г., Кийн, М. (1999). Передача знаний на предприятии: основные фазы и факторы влияния. Проблемы теории и практики управления. № 4, С. 4-7.

[25] Каламан, О., Володина, О., Мандрыкин, Д. (2018). Формирование стратегии инновационного развития современного предприятия. Экономика пищевой промышленности. № 2 (10), С. 75-82.

[26] Карлофф, Б. (1991). Бизнес-стратегия: концепция, содержание, символы. Москва : Экономика.

[27] Бабікова, А. В., Шевченко, І. К. (2012). Інтегровані інформаційні системи: аналіз та перспективи впровадження в процес управління підприємством. Проблеми економіки. № 2, С. 23-26.

[28] Вольский, А. И. (2001). Развитие промышленности - основа подъема экономики страны. Экономист. 2001. № 1. С. 11-15.

[29] Верескун, М. В. (2012). Формування системи управління конкурентоспроможністю для великих інтегрованих промислових підприємств. Основи економіки, менеджменту та права. № 3 (3), с. 55-58. 